\title{
Voice phenomena: how many properties behind this label?
}

\author{
Anna Bartra \\ Universitat Autònoma de Barcelona. Departament de Filologia Catalana \\ i Centre de Lingüística Teòrica \\ anna.bartra@uab.cat
}

\section{Why are Voice phenomena worth studying?}

Speakers' intuitions, philosophical categories and traditional grammars have long considered some types of sentences, namely passives and middles, as the reversed or semantically synonymous mirror image of another construction type, namely active sentences. As soon as by Aristotle, pathos was proposed as a category that represented a way of approaching the relationship between participants in a situation or event. In the Romance tradition, grammarians tried to found equivalent forms for the Latin passive and middle paradigms, and considered the periphrastic be-Passive translations as functional and categorical equivalents. But the mismatches between meaning and formal properties, as well as the inadequacy of reproducing the categories of Latin grammar into Romance descriptions, were very soon apparent to grammarians. To illustrate the point, let us remember that Nebrija refused, on morphological grounds, to accept the existence of a passive voice in Spanish.' Two centuries later, Bello also warns about the usual temptation of translating Latin categories, morphologically supported, to Spanish, where the morphological basis does not exist ${ }^{2}$. In current frameworks where semantics reads off the output structures of the syntactic component within a strict homomorphism, mismatches such as two different -but related- structures being the input for the same semantic representation have always been a challenge. Therefore, in all stages of the theory the focus has been swinging between the two poles: the attempt

1. El latín tiene tres voces: activa, verbo impersonal, pasiva; el castellano no tiene sino sola el activa. El verbo impersonal súplelo por las terceras personas del plural del verbo activo del mismo tiempo y modo, o por las terceras personas del singular, haciendo en ellas reciprocación y retorno con este pronombre se; [...]. La pasiva súplela por este verbo soy, eres y el participio del tiempo pasado de la pasiva misma, [...]. «Latin has three voices; active, impersonal verb, passive; Spanish has only the active one. The third person plural or the third person singular with the pronoun se substitute for impersonal verbs [...]» (my translation) (Nebrija, 1492, Cap XI).

2. Si como fue el latín el tipo ideal de los gramáticos, las circunstancias hubiesen dado esta preeminencia al griego, hubiéramos probablemente contado cinco casos en nuestra declinación en lugar de seis, nuestros verbos hubieran tenido no sólo voz pasiva, sino voz media, y no habrían faltado aoristos y paulo y post futuros en la conjugación castellana.» (Bello, 1891: Introducción). 
to account for speaker's intuition -recently in the form of the $\Theta$-Criterion, for instance- and the requirements of simplicity and elegance of the theory ${ }^{3}$.

The relevant question, one that can not be answered in the few lines of these introductory remarks, and which can be considered a sort of research program, is the following: is the speakers' intuition of a semantic equivalence between active and passive sentences ${ }^{4}$ a linguistic property to be accounted formally for or rather is it an interpretive epiphenomenon that loses its sense as soon as we decompose passive sentences in its formal components and properties? As the recent evolution of grammar shows and the papers inside this volume reflect, voice phenomena can be addressed from different perspectives, each one permitting to go a step further in our knowledge of the formal properties involved in them. The basic aim in this volume is to try to discover a little bit more about this intriguing property of languages: the fact that different structures, made up with the same lexical elements but with different functional categories and formal features, express the same event.

\section{Deconstructing the components of Voice. A quick overview}

As has been extensively discussed in the literature, many languages exhibit a number of nearly similar constructions «some of which are fairly close to the passive and others further away from it» $»^{5}$. Any research on Voice and Passive tries to disentangle the many properties implied in passives, middles and related constructions. The first point of disagreement concerns the defining property that characterizes non-active sentences. From one side, the label passive (together with the passivization rule of some versions of the grammatical theory) seems to highlight the property of raising the PATIENT /THEME to the canonical subject position. From another point of view, the elimination of the AGENT and the subsequent impersonal value is the common property of short and long passives, Romance pronominal passives, middles, and absolute participial constructions. Therefore passive sentences and related structures are viewed as a way to demote the agent, to transform an event where the AGENT is overt or present in a way or another to a structure where it is missing (Lyngfelt and Solstad, 2006).

As for periphrastic passives, the two verbal components, the copular verb $\mathrm{BE}^{6}$ and the Past Participle, are independently found in copular sentences, absolute constructions and noun phrases, a fact clearly questioning about the core properties of passive. For instance, many researchers have put the emphasis on the common properties shared by passives and copular structures (Brucart, 1990 developing

3. See for instance Benveniste 1950/1966, 168: «La distinction de 1'actif et du passif peut fournir un exemple d'unes catégories verbale propre à dérouter nos habitudes de pensé: elle semble nécessaire -et beaucoup de langues l'ignorent; simple -et nous avons grande difficulté à l'interpréter; symétrique -et elle abonde en expressions discordantes.

4. We leave aside for the moment the important middles. For the present general purposes middles align with passives.

5. Solstad \& Lyngfelt 2006: 4 .

6. We represent as BE in small caps all copular verbs that acts as auxiliaries in passive sentences, such as Romance descendants of ESSE, German werden and so on. 
the insights about small clauses in see 1981). Structuralist and distributionalist analyses highlighted the parallelism between copular and passive sentences, but only scarcely were they put in the same group. ${ }^{7}$ Given the difficulties to draw a sharp division between lexical and functional elements based on formal properties, it has been recognized that there is a scale in the property of being functional to lexical (Corver \& Van Riemsdijk 2001). Copular verbs are sometimes considered functional, sometimes lexical and most often a category halfway between the two poles. A study of the very nature and the properties of the verb $\mathrm{BE}$ is obviously outside the goals of this volume, but it is nonetheless a cornerstone in the analysis of passive sentences (Moro, 2000; Mikkelsen, 2005; den Dikken, 2006).

Past Participles (from now on PPrts), on the other hand, clearly manifest passive properties: they agree with their internal argument:

$$
\begin{aligned}
& \text { Destruida la ciudad, la reina se } \\
& \text { destroy.pr.Fem.Sg } \\
& \text { 'One } \text { them.Sg }_{\text {Fe }} \text { city the city was destroyed, the queen suicided' }
\end{aligned}
$$

Moreover, the relationship between perfectivity and voice has been established long ago. Benveniste's 1952/1966 seminal work has shown that perfect, passive and possession are categories often difficult to dissociate, more precisely, that in some languages the perfect with a genitive complement is a possessive construction close to a passive and equivalent to a transitive active construction; «eius factum est operam» is equivalent in Armenian to «habet factum». Interestingly enough, the perfect selects a genitive phrase denoting the AGENT/POSSESSOR of the object. This could mean that there is (a kind of) syncretism between possessors and agents in the perfect. This construction is alive in many languages, as the example in (2), a (stative) passive from Catalan, reflects:

\section{(2) Aquestes aspirines són fetes de la Bayer.}

And what about middles? Following again Benveniste, the distinction stems from Pãnini, who distinguishes the word 'by another one' from the form 'by itself'. Benveniste also highlights the importance of lexical properties in the voice possibilities of verbs, but states clearly that verb classes are not to be drawn exclusively from a simplistic semantic point of view, but that the entire lexical structure has to be taken into account, focusing on the relationship between the subject and the verb. If we consider middle as a unitary category, defined by properties as the ones listed in (3), Romance and Germanic languages differ in the morphosyntactic properties involved.

(3) a. The subject bears the internal Theta role.

b. No Agent can be overt in the structure.

c. Middles have a generic and/or deontic interpretation.

7. See Alarcos (1973). 
Whereas in English middles seem to be a lexical alternate of the transitive version, as we see in (4a), Romance ones have a morphological exponent, the reflexive pronoun $s e(4 \mathrm{~b} / \mathrm{c})$, the same element found in some unaccusative structures $(4 \mathrm{~d})$, and in reflexive constructions (4e):

(4) a. This screen cleans easily.

b. Esta pantalla se limpia fácilmente.

c. Normalmente los políticos se corrompen.

d. El vaso se rompió.

e. Juan se maquilló.

Middles have to be distinguished from unaccusatives and from passives taking into consideration the argument structure, functional projections and the (possible) empty categories involved. Middles do not express the agent because it receives a generic unspecific interpretation. However, in a sentence like (4a) an AGENT is interpreted. Instead, in an unaccusative structure no agent is interpreted, as the ungrammaticality of (5) shows:

(5) *This screen cleans easily in order to preserve it.

We cannot report here the amount of literature devote to middle constructions in the last twenty years (see Keyser \& Roeper, 1984; Hoekstra \& Roberts, 1993; Hale \& Keyser, 1986; Mendikoetxea, 1999, 2012 ; Stroik 1999 among others, and references therein).

In Romance languages, middles are (at least apparently) related to pronominal passives.

Romance pronominal passives share with middles the property of not admitting Agent PPs. ${ }^{8}$ From the eighties on, the analysis of pronominal passive constructions has also focused on the way they obey Burzio's generalisation and how their functional projections interact with the pronoun and the internal argument to achieve agreement and Case relations (Burzio, 1982; Belletti, 1982; Manzini, 1986; Cinque 1988). Within the Mininimalist Program, the properties of the Romance (reflexive, impersonal, middle and passive $\mathrm{SI} / \mathrm{SE}$ ) have received a fine-grained analysis in work like D'Alessandro, 2004, which establishes new proposals on crucial aspects like the phasehood of $v$ or the defectiveness of agreement.

Functionalist perspectives have put the focus on the discourse differences of the different voices. So, passives can be seen as a way to topicalize the internal argument together with, as we mentioned before, the demotion or disappearance of the agent. But, what is the role of the Agent in long passives if passivisation is

8. A special case is constituted by legal language, where two factors conspire in favour of the maintenance of Agent PPs: the conservative use of language and the intention to make clear the subject of legal responsibility, as in Los proyectos de ley se aprueban por el Consejo de Ministros ('Law projects are approved by the Ministers Assembly') [http://www.periodistasparlamentarios. org/?p=926] 
a way to elide the agent? Since passive sentences are a way to 'demote' the agent, the Agent PP -if present- receives a discourse-focus interpretation:

(6) The cyclist was run over by a drunk driver.

In active sentences subjects are usually interpreted as topics; the PP in a long passive is a way to focalize the agent. This situation is congruent with the interpretation that adjuncts receive in general:

(7) John broke the window with a hammer.

In (7), the focused element is with a hammer. In (8), the focused elements can be with a hammer or to avoid suffocation, depending on the context and pragmatic factors:

(8) John broke the window with a hammer to avoid suffocation.

In some cases, this standard interpretation of the Agent PP comes into a conflict with the fact that the Agent PP seems to be obligatory. Why is it that with some verbs short passives are ungrammatical, but long passives are grammatical? The contrast arises with verbs of 'doing': verbs of construction and creation:

(9) a. This house was built / designed/ constructed *(by a French architect)

b. *Tomatoes are grown; The best tomatoes are grown *(by organic farmers)

c. This house was built yesterday / in ten days / in a bad part of the town / only with great difficulty

d. (The best) tomatoes are grown in Italy / organically

As can be seen in (8c/d), the Agent PP is not the only possibility available to rescue the sentence: other adjuncts such as locative, temporal or modals are too.

As first pointed out by Grimshaw \& Vikner (1993), the problem with the bad strings in (9) is restricted to passive sentences built with certain verbs, namely a subset of accomplishment verbs; therefore the contrast is related to the event structure of the verbs. Following Grimshaw \& Vikner (1993), these verbs have a two place event structure: the process and the (final) state or result. The agent licenses the process, whereas the theme licenses the (resulting) state. Since the passive erases the agent, if there is no Agent expressed as a PP, the process part of the change of state event cannot be licensed. The authors draw as a first consequence from their analysis the need to separate argument structure from aspect/event structure. Secondly, themes must be divided in subsets, because only a subset of the change of state verbs behaves like the ones in (9); creation verbs need an APP in the passive, but not destruction verbs:

9. The examples in (5) are taken from this work, also. 
(10) a. The parliament has been destroyed (by the enemy's weapons).

b. John was murdered.

As a third consequence, these facts are incompatible with the analyses of the 'absorption' of the agent Theta role by a morphological element, like the Past Participle morpheme - en, as in Jaeggli (1986) and Baker \& al. (1989) ${ }^{10}$, since if this were the case, short passives would be always grammatical, contrary to data. The restrictions do not only affect standard be-passives; prenominal participles give also ungrammatical phrases without a determiner:

(11) a. ??a photographed building / a grown tomato. ${ }^{11}$

b. a much-photographed building/a locally-grown tomato.

As mentioned before, not only APPs rescue these constructions, but also aspectual prefixes, adverbs, among other modifiers:

(12) *a built house, a rebuilt house, a recently built house. ${ }^{12,13}$

Another point of contact can be established between passive and copular sentences. Chomsky (1981: 117 and ff.) established a scale between the categories 'full verbal' and 'full adjectival', mainly to obtain descriptive adequacy for the properties of verbal passives, lexical passives and copular sentences. With the binary-feature categorization of lexical elements, full verbs were considered to be $[+\mathrm{V},-\mathrm{N}]$, The Past Participles of passive sentences categories were $[+\mathrm{V}]$, a neutralized category with the [-N] feature missing. The predicates of lexical passives and copular sentences, being full adjectives, were $[+\mathrm{V},+\mathrm{N}]$. Lexical passives are highly idiosyncratic, following Chomsky, and have a stative interpretation alike to copular sentences.

In many languages, the difference between lexical and syntactic passives manifests / shows up in the selection of different auxiliaries. In German, the eventive passive is constructed with werden, and the lexical passive with sein:

(13) a. Die Reifen werden aufgepumt. ${ }^{14}$

the tires become up-pumped.

'The tires are being inflated.'

b. Die Reifen sind aufgepumpt. the tires are up-pumped.

'The tires are inflated.'

10. See below.

11. Examples from Grimshaw \& Wikner (1993: 152).

12. Ibid.

13. For a hypothesis on the prefix re- and its influence on the syntactic properties of the VP, see Keyser \& Roeper (1992).

14. From Gehrke (2011), available at http://parles.upf.edu/llocs/bgehrke/home/adjpass-paris11.pdf 
Some Romance Languages make a distinction between passives and copular sentences on one hand, and lexical stative / result passives on the other, as for auxiliary verbs:

(14) a. Las paredes son pintadas anualmente ${ }^{15}$ (SYNTACtic Passive)

the walls are painted yearly

'The wall are being painted every year'

b. Las paredes son verdes (COPUlar SENTENCE)

'The walls are green'

c. Las paredes estan pintadas / despintadas / inacabadas (LEXICAL PASSIVE, Resultative Meaning)

'The walls are painted'

As the prefixed Past Participles in (14c) show ${ }^{16}$, in these varieties lexical resultative passives are clearly set apart from adjectival copular sentences.

Departing from Chomsky (1981), subsequent research has highlighted the role of aspectual projections in the facts depicted in (14).

Summing up, voice phenomena pose a challenge to any theory that postulates the semantic interpretation to be constructed with the syntactic structures as input. Also, some features of constructions in which some version of Voice is involved are shared by other types of constructions. All this facts make especially interesting to try to single out the defining properties and the limits of voice phenomena.

\section{A first step: the traditional grammar's heritage: phrase structure rules and transformations.}

From the very beginning of formal linguistics theories, the challenge has been to account for the rules or mechanisms that connect syntactic representations to semantic representations. Even if the theoretical frameworks have clearly evolved during the last few decades, the general picture has remained unchanged, namely the idea that syntactic representations are the input to Semantic Interpretations. Since a mechanism is needed, «We are concerned with a special case of recursive procedures, generative grammars Gi, each of which enumerates a set of hierarchically structured expressions, assigning to each a symbolic representation at two interfaces, the sensorimotor interface SM for external realization ER and the con-

15. Eventive passives with the verb in Present are rather marginal in Spanish and Catalan, but this issue is outside the scope of the present work.

16. See the ungrammatical strings in (i) and (ii):

(i) ??Han despintado las paredes have $_{\text {PRES.3.PL }}$ unpainted the FEM.PL. walls $_{\text {. }}$ 'They have "unpainted" the walls'

(ii) *Han inacabado las paredes have $_{\text {PRES.3.PL }} *$ unfinished the $e_{\text {Fem.PL. }}$ walls 'They have *unfinished the walls' 
ceptual-intentional interface $\mathrm{CI}$ for what is loosely termed thought: interpreting experience, reflection, inference, planning, imagining, etc. In this respect each Gi can be regarded as an instantiation of the traditional Aristotelian conception of language as sound with meaning (though sound is now known to be only a special case of ER).» (Chomsky 2014: 2) the intuitively recognized relation between actives on one side, and passives and middles on the other must still receive a clear-cut explanation. The universally accepted assumption has been that active and passive are semantically equivalent, at least with reference to the thematic and lexical content. Discourse related properties did not receive attention at all in the first stages of generative grammar, being attributed to the periphery of the grammar; therefore, the fact that active and passive sentences could differ in this respect was not addressed.

Following traditional grammars, then, passive sentences were considered a transformed mirror image of the active one. In a framework in which all types of sentences had to be generated by the grammar, Chomsky (1957: 43) explicitly argued that passive sentences are not part of the kernel of grammar. Rather phrase structure rules generated active sentences and a transformation reversed the order of NPs and introduced the verb be and the $\mathrm{P}$ by. A transformation of the form in (1) related the sentence in (2a) with one in (2b):

(15) If $\mathrm{S} 1$ is a grammatical sentence of the form

$$
\text { NP1 - Aux - V - NP2 }
$$

Then the corresponding string of the form

$\mathrm{NP} 2-\mathrm{Aux}+$ be + en $-\mathrm{V}-$ by $+\mathrm{NP} 1$

is also a grammatical Sentence

(16) a. John $-\mathrm{C}$ - admire - sincerity

b. sincerity $-\mathrm{C}+\mathrm{John}+$ en - admire - by + John

The first attempt to restrict the overgenerating rule of passive formation came along with the refining of verb classes. Since a clear correlation can be established between verbs that accept a Manner complement and verbs than can passivize (i.e.: agentive verbs), a base rule introducing the Manner Adverbial was in fact the trigger of the possibility that the Passive transformation could apply. The Manner Adverbial «should have as one of its realizations a «dummy element» signifying that the passive transformation must obligatorily apply.» (Chomsky 1965: 103104). This means that a phrase structure rewriting rule as (3a) triggers the transformation once implemented as in (3b):

(17) a. Manner $\rightarrow$ bynPassive

b. $\mathrm{NP}-\mathrm{Aux}-\mathrm{V}-\ldots-\mathrm{NP}-\ldots-$ by^Passive $-\ldots$

This was the first step in the path to dispense with ad hoc rules restricted to specific sentence types. The facts in (18)- (19) were now accounted for: 
(18) The verbs that allow the Passive transformation also allow for a Manner Adverbial. This class of verbs are agentive verbs.

(19) Passives are not restricted to transitive verbs:

a. John is looked up to by everyone.

b. The boat was decided on by John.

The paradigm changed dramatically in the Principles and Parameters Theory. Two theoretical constructs passed away at the same time: rules and labels such as «passive sentence», «relative sentence» as names of specific constructions. 'Sentence types', like passive or relative, began to be considered traditional labels for a bunch of properties, this is to say epiphenomena. Rules were made more general and abstract, approaching the rule Move-a. ${ }^{17}$ Move $\alpha$ is a general rule obeying several constraints, mainly restrictions on the trace or variable left behind by the category that is being moved and on the landing site of the category. In the case of passives, the moved element reaches an A-position which has to be empty in order to avoid a $\theta$-Criterion violation. The motivation for the NP to move is the inability of passive verbs (together with unaccusatives) to assign Structural Accusative Case due to the categorical specification of Passive Participles as [+V], lacking the [-N] feature, the one responsible of the assignment of (Accusative) Case. The correlation between the lack of Accusative assignation to the internal argument and of $\theta$-role to the subject, known as Buzio's generalization, is reproduced in its original form (Burzio 1986: 185) in (4), where A stands for 'Accusative' and $\theta \mathrm{S}$ is transparent:

(20) $\theta \mathrm{S} \leftarrow \rightarrow \mathrm{A}$

The facts that could be related in the P\& P framework are the ones in (21) to (25):

(21) Thanks to Burzio's correlation and the analysis of Move $\alpha$ in order to pass the Case Filter, passives are similar to the structures with unaccusative verbs.

(22) The rule moving the NP internal argument to subject position-Move $\alpha$ - is identical to and is triggered by the same facts that account for the sentence

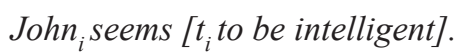

(23) Given the characterization of lexical categories based on the two features [+/$\mathrm{V}]$ and $[+/-\mathrm{N}]$, similar structures can be obtained by a syntactic operation or in the lexicon, i. e., syntactic passives and lexical ones. In the latter ones, a (morphologically complex) lexical element assigns an 'internal' $\theta$-role to its subject, as in

\section{Antarctica is unhabited.}

17. «The notions 'passive', 'relativization', etc., can be reconstructed as processes of a more general nature, with a functional role in grammar, but they are not 'rules of grammar'» (Chomsky, 1981: 7). 
(24) Passives with a sentential internal argument have the same explanation except for the fact that the sentence can remain in situ and an expletive element is inserted in the subject position which has no $\theta$-role assigned to:

\section{It was believed that the conclusion was false}

(25) Passivization is not restricted to the categorical status [+V] of the past participle. Passive morphology, as in Latin, Hebrew, and other languages can also inhibit the assignation of Accusative Case. Also pronominal passives from Italian or Catalan can be explained the same way. In this case the reflexive pronoun is allegedly the 'absorber' of Accusative Case:

\section{a. Le mele si mangiano \\ b. Ara es mengen moltes pomes}

Summing up, from the Principles and Parameters Theory on, the different properties traditionally associated to passives were segregated into minimal properties affecting the principles of grammar. There was no more need for separated rules for be and pronominal passives, for instance. The relationship between active and passive sentences, what we called «the spaeker's intuition» was technically preserved through the UTAH:

(26) Uniformity of Theta-Assignment Hypothesis (UTAH):

Identical thematic relationships between items are represented by identical structural relationships between these items at the level of D-structure. (Baker 1988:46)

The wish to motivate Burzio's generalization, the UTAH, and the correlations established for passive sentences in the Principles and Parameters Theory has led to several developments in the eighties. Jaeggli (1986: 591) assumed that in a (be-) passive the «the external Theta-role has been assigned to the passive suffix» and also that «the passive suffix -en is assigned (and requires the assignment of) objective Case (ibid.: 595). This hypothesis was further developed in Baker, Johnson \& Roberts (1989) ${ }^{18}$, who related the suffix -en to the $\mathrm{I}^{0}$ position. Since the fact that by-phrases receive an Agent interpretation also needs an explanation, a further assumption is made: the Agent Theta role is transmitted from the passive suffix to the by-phrase by a process of percolation through the branching nodes dominating the PP. The by-phrase is not an argument of the verb. Rather, the NP is an argument of the $\mathrm{P} b y$, and the whole $\mathrm{PP}$ is an (optional) argument of the -en suffix. This approach, however, is not exempt of theory-internal problems. Theta-role and Case absorption by the PP-suffix would be clearer in a language, which, as Romance ones, PP suffixes show evident nominal properties such as Gender and Number

18. Fort he sake of simplicity we will refer to both papers generically as to Jaeggli's Hypothesis if no further clarification is needed. 
agreement. Moreover, the $\mathrm{P}$ by assigns the same Theta-role in Passives and in other PPs, a fact that should be considered a mere coincidence in Jaeggli's account.

As we saw, two properties intervene in voice and passivization phenomena. On the one hand, the lexical-aspectual properties of the verb restrict the passivization possibilities, and, on the other hand, the functional-inflective properties of the sentence act as the trigger of movement. In the late nineties two (apparently independent) developments in linguistic theory converged to posit a new paradigm, which related in some way the lexical and case-inflectional properties in an explanation of passive constructions that could, at the same time, explain the properties shared with related constructions. The split between functional and lexical categories allowed rephrasing Burzio's generalisation by at the same time avoiding ad hoc correlations between properties and relating the licensing of the external argument and the possibility of passive the same category.

\section{Small $v$ and Voice P: one or two categories needed?}

The latest developments on Voice are related in a way or another to the categories $v \mathrm{P}$ and VoiceP. The crucial point to start with is the relation between the 'special' status of the external argument (see Chomsky 1981, Stowell 1981, 1982, Koopman $\&$ Sportiche 1991, and ff.) and transitivity. The attempts to account for this relation by considering the VP a small clause with an 'extra' level at which the external argument adjoined, had the additional cost of distorting the basic assumptions about phrase structure such as the X'-bar Theory.

From Kratzer (1996) on, a paper that made a qualitative leap forward in the explanation of the singularity of subjects in front of other arguments, the relationship between voice and the subject has received a formal explicit status on the syntax-semantics interface. At the same time, in the framework of lexical syntax, Hale \& Keyser $(1993,2002)$ established that the external argument is not part of the lexical structure of verbs; rather it is introduced at overt syntax by a functional category. The external subject is introduced by a (functional) light verb. Chomsky (1995 \& ff.) adopted small $v$ as the locus of the external argument, a position whose properties have a significant influence on voice phenomena:

(27) «The internal arguments occupy the position of specifier and complement of $\mathrm{V}$. Accordingly, the extermal argument cannot be lower than [Spec, $v$ ]. If it is [Spec, $v$ ], as I assume, then the $v$-VP configuration can be taken to express the causative or agentive role of the external argument. It would be natural to extend the same reasoning to transitive verb constructions generally, assigning them a double-VP structures as in (115) $\left(\left[v^{\max }[v\right.\right.$ [VP [ ...V...] ] ] abk transcription from the tree), the agent role being understood as the interpretation assigned to the $v$-VP configuration. (Chomsky 1995: 315)

Chomsky assumes that «only unaccusatives lacking agents would be simple VP structures» (ibid. 316), a property that will be later on extended to passives. Since unergatives and transitives share the property of having an external CAUSER 
argument, Chomsky (2006) distinguishes between $v$ and $v$ *being the latest one the only «complete» verbal category:

(28) Let's adopt the (fairly conventional) assumption that verbal phrases are of the form $\mathrm{v}-\mathrm{VP}$, where $\mathrm{v}$ can be $\mathrm{v}^{*}$, the functional category that heads verb phrases with full argument structure, unlike unaccusatives and passives. (Chomsky 2006: XXX).

For passives, the smallest domain where the 'object' DP can receive its $\theta$-role and can be licensed is $\mathrm{TP} / \mathrm{CP}$, not $v \mathrm{P}$, as $v \mathrm{P}$ is defective and has no accusative features to check.

Whereas for some authors, the different 'flavours' of v suffice to account for the differences between active transitive constructions on one hand, and unaccusative and passives on the other, this desirable simplification runs into problems when faced to the facts in some languages (Alexiadou, 2012; Alexiadou \& Doron 2012; Harley, 2013).

The functional category $v \mathrm{P}$ presumably plays also an important role in the licensing of the Agent PP. Collins (2005) addresses the puzzling question of the nature, semantic interpretation and licensing of by-Phrases in long passives, and assumes a (controversial) analysis in which it is generated in the same position as the external argument. This very appealing approach has the cost of positing a smuggling movement in order to avoid the violation of the local constraints.

\section{Past Participles, Perfects, inner Aspect and grammatical aspect}

Lexical-aspectual restrictions in passives are related to the two kinds of Aspect, inner (Aktionsart or lexical structure in Hale \& Keyser's sense) and outer or sentence-related.

As for inner Aspect, the lexical structure of the verb is the responsible of the different degree of grammaticality and acceptability of the sequences in 4 .

(29) a. *El llanto de un niño es llorado (Mendikoetxea, 1999: 1621).

b. *Son construidas casas por los albañiles (Ibid.: 1622).

c. *Unos cien metros fueron corridos por los atletas (Ibid.: 1622).

d. ??Fueron hechas muchas visitas a los enfermos (Ibid.: 1622).

The general simple view is that, form the four types of predicates first identified by Vendler (1967), only accomplishments admit freely the passive. States and activities cannot because they are unbounded, they have no endpoint. That would cover the facts in (29). Achievements do not have internal duration and are restricted to punctual verbal tenses: they are very marginal in the present or durative past. In a more accurate view, such as Hale \& Keyser's one, the objects in (29a/b) are not the endpoint of an event. Llorar and correr are unergative verbs with a lexical structure in which a N LLORO/LLANTO or CARRERA have incorporated or conflated 
into a verbalizing position; therefore, the direct object is a kind of cognate hyponym of the lexical root of the verb. A similar account can be given to (29c), where the measure direct object is not the real object, but a quantificational modifier of the incorporated N. As for (29c), construir can be interpreted as an accomplishment with a definite object; with a bare NP it is unbounded. The same structure can be attributed to (29d), where the light verb hacer fulfils the verbalising place and the apparent object muchas visitas is the predicate $\mathrm{N}$.

From Benveniste on, research on perfectivity and on the properties of past participles to passive sentences has produced a huge amount of research in many theoretical frameworks. ${ }^{19}$ Related to this, a very promising line od research treats Voice phenomena and the syntactic variation and restriuctions by 'deconstructing' all the components intervening in passives. As for BE passives, both the copular verb and the properties of PPs have to be analysed (Embick, 1997; Embick 2000; Alexiadou, Rathert \& von Stechow, 2003, Gehrke \& Grillo, 2009, a.o.).

The restrictions on passives have to do with the interaction of three factors: the aspectual value of the morphological tense of the verb, the inner aspect or Aktionsart of the verb, and the fact that the PP has its own aspect: a perfective one. This line of research is followed by Bosque's paper in this volume. Bosque's paper is a fine-grained description and analysis of the lexical, syntactic and semantic properties of Result Past Participles derived from transitive verbs in Spanish. He argues on empirically and theoretically well-supported grounds for a classification much more precise that the existing ones. The paper offers many evidences to separate several factors determining the bunch of properties shown by the R-PPts and to identify lexical or inner-aspect factors, grammatical aspect factors, explained by the presence of a silent verb have, voice properties as the externalization of the internal argument. The main data comes from the structures known as reduced relatives, but the author also addresses the compatibility between R-PPrts and the auxiliary verb estar. He also shows that previous accounts of the (im)possibility of estar with PPrts are not accurate enough and that a more subtle analysis is needed. Following Bosque, the relevant interpretation of result that allows us to explain the compatibility of the PPrt and estar is the one that relies on the temporal use derived from the presence if the silent verb HAVE. The research carried out has further consequences as for the explanation of the restrictions and (in)compataibilities between R-PPrts and other auxiliary verbs like quedar, verse, among others.

Much discussion came up concerning the functional categories over the lexical VP that are responsible of introducing and licensing the external argument. Two

19. Interestingly enough, these restrictions had been noticed by traditional grammarians. In the Spanish/ Catalan area, works by Fernández Ramírez (1951) and Coromines (1972) are especially relevant. Coromines, for instance, noticed that achievements (called by him 'accions puntuals') could never appear in Catalan in the present or past continuous tense:

(i) La inscripció és descoberta pel president the inscription is discovered by-the president

(ii) Els documents eren retirats de la taula del secretari the documents were-being taken from the table of-the secretary 
fundamental lines of research are worth mentioning. Chomsky (1995 and ff.) argues for different values / properties of the functional category $\mathrm{v}, \mathrm{v}$ and $\mathrm{v}^{*}$, where, as mentioned, only $\mathrm{v}^{*}$ is a fully developed that can introduce an external argument (see also Harley, 2009, or the 'flavours' of $v$ ). The other stream of research, stemming from Kratzer (1996), proposes that VoiceP introduces the external argument. The interplay between the lexical structure of verbs and the functional categories of the VP layer is a topic of much research in recent literature (Folli and Harley, 2005; Alexiadou); several researchers have discussed the possibility that both categories, $\mathrm{v}$ and Voice, are needed to account for the morphosyntactic and semantic intricacies of passive and passive-like structures. Harley (2013) has shown on the basis of Hiaki data that if Baker's (1998) Mirror's Principle is to be maintained, Voice $\mathrm{P}$ and $\mathrm{vP}$ are both needed in order to account for the fact that agentive verbalizing morphology and the introduction of verbal arguments -supposed to be introduced by $\mathrm{vP}-$ is not on complementary distribution to passive alternations. Much of the Alexiadou's paper in this volume is another strongly grounded contribution in this sense. The author makes a fine-grained analysis of the properties of middle and reflexive structures in Greek compared to those of English. Alexiadou argues that semantic properties and labels have to be separated from syntactic and formal properties. From a semantic point of view, 'middle' can be adequately used to refer to (the semantic property of) ascribing a dispositional property to the patient/theme argument. This semantic property is differently encoded in languages: middles and reflexives are active / unergative in English and middle / unaccusative in Greek. Following Alexiadou, some languages like English have a Passive FC over VoiceP. VoiceP is responsible of introducing the external argument. Other languages, like Greek, have Middle Voice as one of the shapes of Non-active Voice. In these languages, middles act as unaccusatives.

The topic of the values of the functional category $\mathrm{v}$ is also pursued in van Gelderen's paper from a diachronic point of view. This author focuses on a topic indirectly related to Voice: how the different flavours of $\mathrm{v}$ evolve along the history of language, namely English, and she is concerned with as a recognized unstable class of verbs: psich verbs. Specifically most have evolved from an object-experiencer argument structure to a subject-Experiencer status. The author argues that the change in the staturs of $\mathrm{v}$ from a causativizer to a stative head caused the structures to be ambiguous and the experiencer tot be interpreted as the subject. This analysis has consequences to be explored on the possibilities of psich verbs to passivize in different stages of the language.

Research on language disorders as well as on language acquisition is of special interest not only for the very purpose of discovering the exact nature of the impaired behavior and its linguistics properties related to other cognitive disorders and in relation to the Typically developing or Typically Behaving people, but also because they can be used as a test to check linguistic hypotheses. Gavarró \& Heshmati's paper presents the results of an experiment on the comprehension of long and short passives in Persian ASD affected children. The authors present exhaustively the results obtained and compare them to the results of similar experiments carried out for Greek and Danish ASD children. They conclude that highly Performing Children behave 
like Typically Developing Children whereas, Low Performing Children behave have also a Low comprehension performance of passive sentences.

\section{References}

Alexiadou, A., Rathert, M., \& von Stechow, A. (Eds.). (2003). Perfect explorations (Vol. 2). Walter de Gruyter.

Baker, M., Johnson, K., \& Roberts, I. (1989). «Passive arguments raised». Linguistic inquiry, 219-251.

Belletti, A. (1982). Morphological passive and pro-drop: The impersonal construction in Italian. Journal of Linguistic Research, 2(4), 1-34.

Benveniste, Émile (1950/1966). «Actif et moyen dans le verbe», Journal de Psychologie. Repr. in Problèmes de linguistique générale. Paris, Gallimard, 1962: 168-175.

Benveniste, Émile (1952). «La construction passive du parfait transitif», Bulletin de la Société de Linguistique de Paris, XLVIII. Repr. in Problèmes de linguistique générale. Paris, Gallimard, 1962: 176-186.

Brucart, J. M. (1990). Pasividad y atribución en español: un análisis generativo. Estudios de Lingüística de España y Méjico, México: uNAM, 179-208.

Burzio, L. (1986). Italian syntax: A government-binding approach (Vol. 1). Springer.

Chomsky, Noam (2007). Approaching UG from below. Interfaces + recursion $=$ language, 1-29.

Chomsky, Noam (2014). «Minimal Recursion: Exploring the Prospects» in Roeper, Thomas \& Margaret Speas (eds.) Recursion: Complexity in Cognition. Springer: $1-16$.

Cinque, G. (1988). On si constructions and the theory of arb. Linguistic inquiry, 521-581.

Coromines, Joan (1974) «La passiva pronominal és generalment correcta i sovint no ho és la passiva amb ésser», in Lleures $i$ converses d'un filòleg. Barcelona : Club Editor: 77-82.

Corver, N., \& van Riemsdijk, H. (eds.) (2001). Semi-lexical categories: the function of content words and the content of function words (Vol. 59). Walter de Gruyter.

D’Alessandro, R. (2007). Impersonal «si» constructions: Agreement and Interpretation. Amsterdam, Walter de Gruyter.

Embick, D. (1997). Voice and the interfaces of syntax. Ph.D. U Penn.

Embick, D. (1998). Voice systems and the syntax/morphology interface. MIT working papers in linguistics, 32, 41-72.

Fernández Ramírez, Salvador (1951). Gramátyica española. 4. El verbo y la oración. Vol. ordenado y completado por Ignacio Bosque. Madrid, Arco Libros, 1986.

Folli, R., \& Harley, H. (2005). Flavors of v. Aspectual inquiries, 95-120.

Grimshaw, J., \& Vikner, S. (1993). Obligatory adjuncts and the structure of events. In Reuland, Eric \& Werner Abraham (eds.), Knowledge and language II: 143-155. Springer Netherlands.

Hale, K., \& Keyser, J. (1986). Some transitivity alternations in English. Anuario del Seminario de Filología Vasca «Julio de Urquijo», 20(3), 605-638.

Hale, Ken \& Samuel J. Keyser, (1993). On argument structure and the lexical expression of syntactic relations. In Hale, Ken \& Samuel J. Keyser (eds.), The view from Building 20. Cambridge, Mass., The MIT Press: 53-109. 
Harley, H. (2009). «The morphology of nominalizations and the syntax of vP». In Rathert, Monika and Giannankidou, Anastasia (ed.), Quantification, Definiteness and Nominalization. Oxford, UK: Oxford University Press, 320-342.

Harley, Heidi (2013). «External arguments and the Mirror Principle: On the distinctness of Voice and v», Lingua 125 (2013) 34-35.

Hoekstra, Teun, and Ian Roberts (1993). Middle constructions in Dutch and English. In Reuland Eric and Werner Abraham (ed.), Knowledge and language. Vol. 2, Lexical and conceptual structure. Dordrecht: Kluwer, pp. 183-220.

Jaeggli, Osvaldo. A. (1986). «Passive». Linguistic inquiry, 587-622.

Keyser, S. J., \& Roeper, T. (1984). On the middle and ergative constructions in English. Linguistic inquiry, 381-416.

Keyser, Samuel. J., \& Roeper, Thomas. (1992). «Re: The abstract clitic hypothesis». Linguistic Inquiry, 89-125.

Koopman, Hilda \& Dominique Sportiche (1991). The position of subjects. Lingua, 85(2), 211-258.

Kratzer, A. (1996). «Severing the external argument from its verb.» In Rooryck, J., \& Zaring, L. (Eds.). Phrase structure and the lexicon. Springer Netherlands: pp. 109-137.

Manzini, M. R. (1986). On Italian Si in Borer, H. (ed.) Syntax and semantics, 19: The Syntax of Pronominal Clitics, New York, Academic Press: 241-262.

Mendikoetxea, A. (1999). Construcciones con «se»: medias, pasivas e impersonales. In Bosque, I. And V. Demonte (ed.) Gramática descriptiva de la lengua española. Madrid, Espasa Calpe: 1575-1630.

Mikkelsen, L. (2005). Copular clauses: Specification, predication and equation, Amsterdam: John Benjamins.

Moro, A. (2000). Dynamic antisymmetry . Cambridge, mass.: The MIT Press.

Perlmutter, D. M. (1978). «Impersonal passives and the unaccusative hypothesis». In Proceedings of the annual meeting of the Berkeley Linguistics Society (Vol. 4).

Raposo, E., \& Uriagereka, J. (1994). Indefinite se (ms.). University of California, Santa Barbara and University of Maryland (quoted by Elena De Miguel, 1996).

Roberts, I. (1987). The representation of implicit and dethematized subjects. Berlin: Walter de Gruyter.

Rooryck, Johan (1997). «On passive as partitive quantification». In di Sciullo, Anna Maria (ed.) Projections and Interface Conditions: Essays on Modularity. Oxford University Press: 201-234. (Language \& Linguistics: Grammar 415).

Solstad, Torgrim, \& Lyngfelt, Benjamin (2006). Perspectives on demotion. In Solstad, T., \& Lyngfelt, B. Demoting the Agent. Passive, middle and other voice phenomena. Amsterdam: John Benjamins: 1-20.

Stowell, Timothy A. (1981). Origins of phrase structure (Doctoral dissertation, Massachusetts Institute of Technology).

Stowell, Timothy A. (1982) «Subjects across categories.» Linguistic Review (The) Utrecht, 2(3), 285-312.

Stroik, Thomas (1999). «Middles and reflexivity», Linguistic Inquiry, 30 (1): 119-131.

Suñer, M. (1990). Impersonal se passives and the licensing of empty categories. Probus, 2(2), 209-232.

Vendler, Zeno 1967. Linguistics in Philosophy. Ithaca: Cornell University Press. 